\title{
THE PROPERTIES OF FERMENTED BEEF PRODUCTS RIPENED AS ENTIRE PRIMAL CUTS OF M. SEMITENDINOSUS, M. SEMIMEMBRANOSUS AND MM. PSOAS MAJOR AND MINOR*
}

\author{
Ewelina Węsierska ${ }^{1 \bullet}$, Marek Szołtysik², Władysław Migdał ${ }^{1}$ \\ ${ }^{1}$ Department of Animal Products Technology, University of Agriculture, Balicka 122, \\ 30-149 Kraków, Poland \\ ${ }^{2}$ Department of Animal Products Technology and Quality Management, University of Environmental \\ and Life Sciences, Chełmońskiego 37/41, 51-630 Wrocław, Poland \\ •Corresponding author: e.wesierska@ur.krakow.pl
}

\begin{abstract}
The physico-chemical, biochemical and microbiological changes in raw fermented beef products, manufactured from semitendinosus (ST), semimembranosus (SM), psoas major and minor (PM) muscles during ripening were evaluated. The accumulation of free fatty acids $(1550,2660,1850$ $\mathrm{mg} / \mathrm{kg}$ ) and the increase of lactobacilli (about $0.2 \mathrm{log} \mathrm{cfu} / \mathrm{g}$ ) had an effect on the $\mathrm{pH}$. The low $\mathrm{pH}$ (4.9) reduced the coagulase-negative cocci population $(0.2 \mathrm{log} \mathrm{cfu} / \mathrm{g})$ and affected the free amine groups content (185.2 and $25 \mu \mathrm{M} \mathrm{Gly} / \mathrm{kg})$ in the PM with the lowest fat content $(2.9 \%)$. At the end of the ripening process the ST contained a similar quantity of water, protein, fat and proteolysis products as the SM, however small peptides were generated in all products. The release of volatile compounds could be affected by the drying mainly due to the increase of fat (free fatty acid transformations) and activity of bacterial cells (amino acid transformations, fermentation under aerobic or anaerobic conditions). The results of a two-way analysis of variance for physico-chemical, biochemical and microbiological attributes showed that all the analysed factors significantly influenced the level of the evaluated variables in the $S T, S M$ and $P M$ products $(P<0.01)$ excluding the type of product and its effect on the fat, ash, 2-phenylethylamine and putrescine content, $\mathrm{pH}$ and the coagulase-negative cocci count in the ST and SM. The interactions between the type of product and the ripening period were highly significant, with the exception of the yeasts and the LAB, existing in the external and internal layer of the products.
\end{abstract}

Key words: beef, microflora, ripening, volatile compounds

Aroma, tenderness and colour are the major quality attributes of raw fermented meat products. They are dependent on the physico-chemical, biochemical and microbiological changes which occur during ripening. The qualitative and quantitative composition of volatile aroma compounds is dependent on the chemical content,

*The study was supported by Grant No. NN312305740 from the Polish Committee of Scientific Research in the Department of Animal Products Technology, University of Agriculture, Kraków, Poland. 
the presence of acidifying and denitrificating microflora as well as on the $\mathrm{pH}$ values. The compounds occurring as a result of free fatty acids oxidation as well as the activity of coagulase-negative cocci are regarded as the main source of aroma precursors (Ansorena et al., 2000; Spaziani et al., 2009; Wójciak and Dolatowski, 2012; Węsierska et al., $2013 \mathrm{a}, \mathrm{b})$. Low values of $\mathrm{pH}$ create the environment for biochemical changes which alter the microstructure and water activity (Lücke, 2000) as well as microbiological activity which determines the final colour of raw meat products (Węsierska et al., 2013 b). The presence of fat influences the texture, oral sensation and juiciness, and salt determines the flavour, water holding capacity, and colour (Olivares et al., 2009). The connection between the biochemical properties and the origin (country, region, recipe, climate conditions, "house microflora" activity) has been partly described, for example for Italian (Moretti et al., 2004; Casaburi et al., 2007; Di Cagno et al., 2008; Spaziani et al., 2009), Spanish (Salgado et al., 2005; Larrea et al., 2006), Portuguese (Roseiro et al., 2008), French (Lebert et al., 2007; Rason et al., 2007), Turkish (Dalmis and Soyer, 2008; Kilic, 2009) and Chinese (Zhao et al., 2008) raw meat products. Most of them have been fabricated from pork cuts as various sausages. Even though Olivares et al. (2009) and Węsierska et al. (2012 a, b) atempted to acquire knowledge about the generation of aroma compounds through the different ripening stages, there is no specific information on the endo- and exogenous biochemical changes in beef fermented products during the ripening, in spite of their advisable chemical and histological composition. It proved reasonable to analyse beef muscles: $m$. semitendinosus, $m$. semimembranosus and mm. psoas major and minor due to the differences in their chemical composition, texture attributes and other properties of quality, changeable during the postmortem cold ageing (Koohmaraie et al., 1988; Klont et al., 1998; Lefaucheur and Gerrard, 2000; Kołczak et al., 2005, 2008). The objective of this study was to evaluate changes in the physico-chemical, biochemical and microbiological properties of raw fermented beef products, ripened as entire primal cuts of m. semitendinosus (ST), $m$. semimembranosus (SM) and mm. psoas major and minor (PM) by the traditional meat fermentation method.

\section{Material and methods}

\section{Processed meat product}

Three raw smoked beef cuts (ST, SM and PM), reclaimed from black-and-white cattle, were manufactured in a small-scale plant using a genuine ripening room and climate conditions. The meat and spices were obtained from local producers (Podlasie region, Poland). The smoking procedures and spice compositions were kept confidential. The meat cuts were preserved and aromatized by dry salt and non-iodinated rock salt and seasoned for one week in cool storage premises at a temperature of $4-7^{\circ} \mathrm{C}$. Nitrite curing was not practised. The excess salt was removed by drenching for about $24 \mathrm{~h}$ (the intended $\mathrm{NaCl}$ content was about 3.5\% in ready-to-eat products). The ST, SM and PM were turned over during the salting, soaking and washing processes. After draining, the products were smoked with cold smoke and ripened at 
$18-20^{\circ} \mathrm{C}$ for 1 week and at $12-15^{\circ} \mathrm{C}$ for a further 3 weeks in a ripening room with a relative humidity of $80-85 \%$. The ready-to-eat ST, SM and PM products assumed the shape of a flattened cylinder and were characterised by a soft, resilient consistency. The meat was dark-red in the cross-section. The flavour was salty, characteristic for raw fermented meats, dependent on the variety and proportions of spices used (the aroma of bay leaf, pepper and juniper was distinguishable). Three batches of production were carried out. Three products, as the replications in each batch, wrapped in a greaseproof paper and packed into thermo-insulated bags in cooling conditions $\left(4-6^{\circ} \mathrm{C}\right)$, were immediately distributed by a courier to various partner laboratories for analysis for up to $24 \mathrm{~h}$.

\section{Sampling}

Samples were primarily collected just before the smoking procedures, after dry salting (time zero). The cuts were next sampled at different times throughout the ripening process (after the 2 nd and 4 th week of the ripening). The content of water, protein, fat, $\mathrm{NaCl}$, soluble nitrogen, free amino groups, free fatty acids and microbial counts was determined in duplicate at each sampling point. Samples for microbiological analysis were taken from the surface (a depth of up to $2-3.5 \mathrm{~cm}$ ) as well as from the internal layers of the products. Each layer was treated as different habitat with heterogenous physico-chemical conditions. At first, three $10 \mathrm{~g}$ slices from each product, without casing, were weighed aseptically, cut into small pieces and placed into sterile stomacher bags. $90 \mathrm{ml}$ of a sterile diluent (Peptone Water, Biocorp) was added and the mixture was homogenized using a laboratory blender (Stomacher 80, Seward). The series of decimal dilutions was prepared with the same diluent according to Polish and European standards PN-A-82055-6,16,17:1994 and EN-ISO 6888:2001/A1:2004. Thereafter, three $20 \mathrm{~g}$ slices were taken for $\mathrm{pH}$ and water activity measurements. After removing the casing, the remainder was comminuted using a kitchen blender (Multiquick Professional, Braun) to obtain a homogenous raw meat mixture for all physico-chemical and biochemical investigations. The collected samples were analysed immediately according to relative standards.

\section{Analysis}

The chemical composition was determined according to the following recommended methods: water content by drying samples to stable weight (Polish standard PN ISO 1442:2000); total nitrogen content by the Kjeldahl method (Polish standard PN-75-A-04018:1975/Az3:2002) with the set type 322 (Büchi); fat content by the Soxhlet method (Polish standard PN ISO 1444:2000); ash content (Polish standard PN ISO 396:2000) and $\mathrm{NaCl}$ content by the Mohr's method (Polish standard PN ISO 1841-1:2002). The water activity was controlled by the LabMaster-aw (Novasina), following the instructions; the $\mathrm{pH}$ was measured with a $\mathrm{pH}$-meter type $\mathrm{CP}-411$ and electrode type PP-3 (Elmetron) in a water homogenate (meat:water 1:3). The free amino groups content was evaluated by the Kuchroo et al. (1983) method using 2, 4, 6-trinitrobenzenesulfonic acid (TNBS) (Sigma). The free amino groups were determined in water and phosphotungstic acid (PTA). The quantity of the groups was indicated from the standard curve prepared with glycine. The quantity of free fatty acids was evaluated using a gas chromatograph (Agilent Technologies 6890N) with 
a mass detector (Agilent Technologies 5973). Analysed chemicals were extracted using a mixture of hexane and 2-ethyl ether $(1: 1 ; \mathrm{v} / \mathrm{v})$, adsorbed on aluminium oxide and next liberated from stationary phase by diisopropyl ether with $6 \%$ formic acid. The conditions of separation: chromatographic column $60 \mathrm{~m} \times 250 \mu \mathrm{m} \times 0.25 \mu \mathrm{m}$, temperature of column from $140^{\circ} \mathrm{C}(5$ minutes $)$ to $240^{\circ} \mathrm{C}\left(4^{\circ} \mathrm{C} / \mathrm{min}\right)$, carrier gas He $\left(20 \mathrm{~cm}^{3} / \mathrm{s}\right)$, injection $1 \mu \mathrm{l}, 260^{\circ} \mathrm{C}$, split $100: 1$. The TBA index was determined by the spectrophotometric method (Rosmini et al., 1996). The absorbance was read at a wavelength of $530 \mathrm{~nm}$. Thiobarbituric acid (TBA) was a reagent in malondialdehyde (MDA) assay. The TBA index was expressed in mg of the MDA per $\mathrm{kg}$ of the product. Biogenic amines were derivatised with dansylchloride, as previously described by Paulsen and Bauer (2007). $90 \mathrm{~g}$ of 10\% (w/v) trichloroacetic acid was added and suspended with an Ultra-Turrax T25 basic homogeniser for 2 minutes to $10 \mathrm{~g}$ of the minced sample (IKA, Germany). The suspension was filtered through a folded paper filter of a $0.45 \mu \mathrm{m}$ pore size. The clear filtrate was used for chemical analysis. The dansylated amines were separated using the HPLC method (high performance liquid chromatograph Hewlett Packard 1050 with UV/WIS detector, Rheodyne dispenser, LiChroCART HPLC 3 Purospher RP-18 $5 \mu \mathrm{m} 25 \mathrm{~cm}$ column and Hewlett Packard 3396 Series II integrator). The amines were detected by UV/VIS absorption (Waters 996 at $254 \mathrm{~nm}$ ). The bacteriological examination was carried out as follows: the microbiological analysis of the total plate count in mesophilic conditions (Plate Count Agar, Biocorp, $30^{\circ} \mathrm{C} / 48-72 \mathrm{~h}$ ); yeasts (Chloramphenicol Lab-Agar, Biocorp, $22^{\circ} \mathrm{C} / 48 \mathrm{~h}$ ), Lactobacilli rods (MRS Lab-Agar, Biocorp, acetic acid was used to reduce the $\mathrm{pH}$ to $5.4,30^{\circ} \mathrm{C} / 24-48 \mathrm{~h}$, in an anaerobic chamber with a $20 \% \mathrm{CO}_{2}$ enriched atmosphere - Sheldon Manufacturing, Inc.); Micrococcus sp. as well as a coagulase-negative and positive Staphylococcus sp. determination (Baird Parker Lab-Agar with a yolk emulsion and/or without sodium tellurite, RPF Suplement, Biocorp - cocci classified on the basis of coagulase activity, $37^{\circ} \mathrm{C} / 24 \mathrm{~h}$ ), Bacillus cereus (Mossel's Bacillus cereus Selective Lab-Agar with a yolk emulsion and polymyxine A, Biocorp - species classified on the basis of the mannitol fermentation capacity, $30^{\circ} \mathrm{C} / 24-48 \mathrm{~h}$ ). Additional isolation and identification of the bacteria from the raw materials using the ATB system, Rapid ID 32 A and ID 32 Staph tests, was conducted following the procedure of the National Committee for Clinical Laboratory Standards (Body et al., 2003). The volatile aroma compounds were extracted from the water homogenate incubated at $50^{\circ} \mathrm{C}$ to obtain a solid phase extraction (PME) using carboxen/polydimethylsiloxane (CAR/PDMS) and carbowax/divinylbenzene (CW/DVB) phases. These compounds were analysed using gas chromatographymass spectrometry methods and the NIST commercial spectrum library. The contents was expressed as relative concentration of volatile aroma compounds in particular period of ripening for each product individually. The effect of the type of products and the time of ripening on the physico-chemical, biochemical and microbiological properties was tested by the analysis of variance (ANOVA) with one-factor: the ripening period (levels: weeks $0,2,4$ ) and two-factors: the ripening period (levels: weeks $0,2,4)$ and the type of product (levels: ST, SM and PM muscles). The Scheffe and Duncan post-hoc tests were used for the comparison of means (the significance of differences was investigated at $\mathrm{P}<0.05$ and $\mathrm{P}<0.01$ ). 


\section{Results}

\section{Physico-chemical properties}

The elementary chemical composition of ready-to-eat beef products was in the normative range for raw fermented hams and loins (Polish standards PN-A82007:1996 and PN-A-82031:2005), however, the salt content was higher than the normative values (3.5-7.0\%) and amounted to 8.5-9.5\%, depending on the product (Table 1). A decrease in water content during the 4-week ripening $(\mathrm{P}<0.01)$ was simultaneous in all products with an increase of protein $(\mathrm{P}<0.01)$, fat $(\mathrm{P}<0.01), \mathrm{NaCl}$ $(\mathrm{P}<0.01)$ and ash $(\mathrm{P}<0.01)$ content of about $4.0 \%, 1.8 \%, 2.9 \%$ and $2.9 \%$, respectively (Table 1), although the ST final product contained a similar quantity of water, fat, $\mathrm{NaCl}$ and ash as the SM. The products dried evenly and consequently, the $\mathrm{a}_{\mathrm{w}}$ (water activity) gradually decreased to $0.85-0.89$, according to the product. In ST and PM products the $\mathrm{a}_{\mathrm{w}}$ decreased similarly by about $0.02(\mathrm{P}<0.05)$ during the first two, and by $0.04(\mathrm{P}<0.01)$ during the last two weeks of ripening, while in SM by about 0.1 and 0.2 , respectively (Table 1 ). The gradual decrease of the $\mathrm{pH}$ was observed in all beef products (Table 1). Although the $\mathrm{pH}$ values of ST and PM products remained almost the same during the first two weeks, after the 2 nd week of ripening they decreased to 5.16 and 4.87 , respectively.

\section{Proteolytic, lipolytic and oxidative changes}

A dynamic increase of the protein degradation products $(\mathrm{P}<0.01)$ was noted between the 2nd and 4th weeks of the ripening in all beef products (Table 2). The amount of free amino groups dissolved in water determined the majority of typical proteolysis products; the amino groups dissolved in PTA proved a low-molecular fraction of singular amino acids as well as di- and tripeptides (Kuchroo et al., 1983). An almost 4-fold increase of free amino groups soluble in water $(\mathrm{P}<0.01)$ was observed in all the smoked meats. ST and SM products contained a similar amount of free amino groups soluble in water and in the PTA at the end of processing while the PM product - significantly less. Small peptides and volatile compounds were generated at the end of the ripening in all products. The advancement of proteolysis was also confirmed by more than a 2 -fold increase $(\mathrm{P}<0.01)$ in the proportion of soluble to total nitrogen in all the ripened meats (Table 2). The gradual increase of the total free fatty acids was observed in all beef products (Table 2) although different acids were affected in different stages of ripening - the amounts of palmitic, stearic and oleic acids were 4- to 13-fold higher $(\mathrm{P}<0.01)$ depending on the product, as compared with the initial quantity. The most dynamic lipolysis was noted in the ready-to-eat SM where the total content of the free fatty acids was markedly higher as compared with the ST and PM products. The amounts of myristic $(\mathrm{P}<0.01)$ and linolenic acids in the ST and PM final products were almost twice as low as in the SM. No acids with shorter $\mathrm{C}<6$ or longer $\mathrm{C}>20$ chains were noted. The value of the TBA index decreased $(\mathrm{P}<0.01)$ during the ripening of all three raw fermented smoked meats (Table 2). 


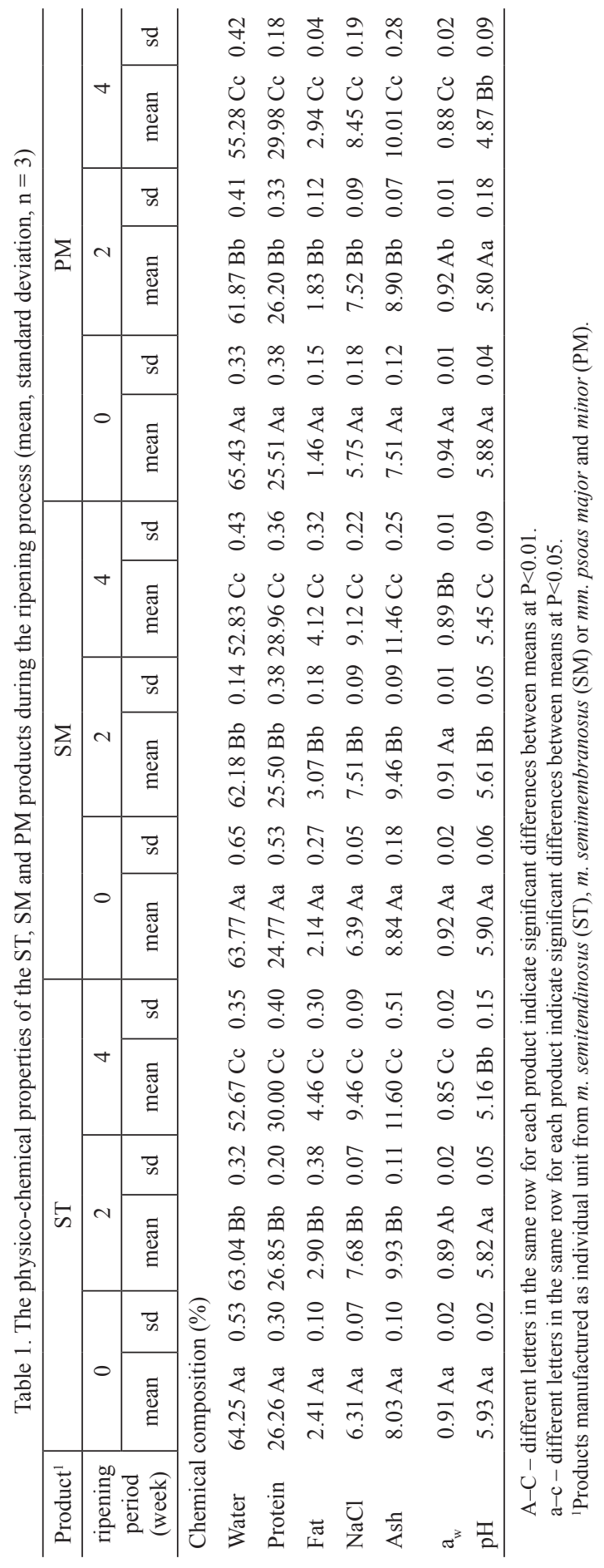




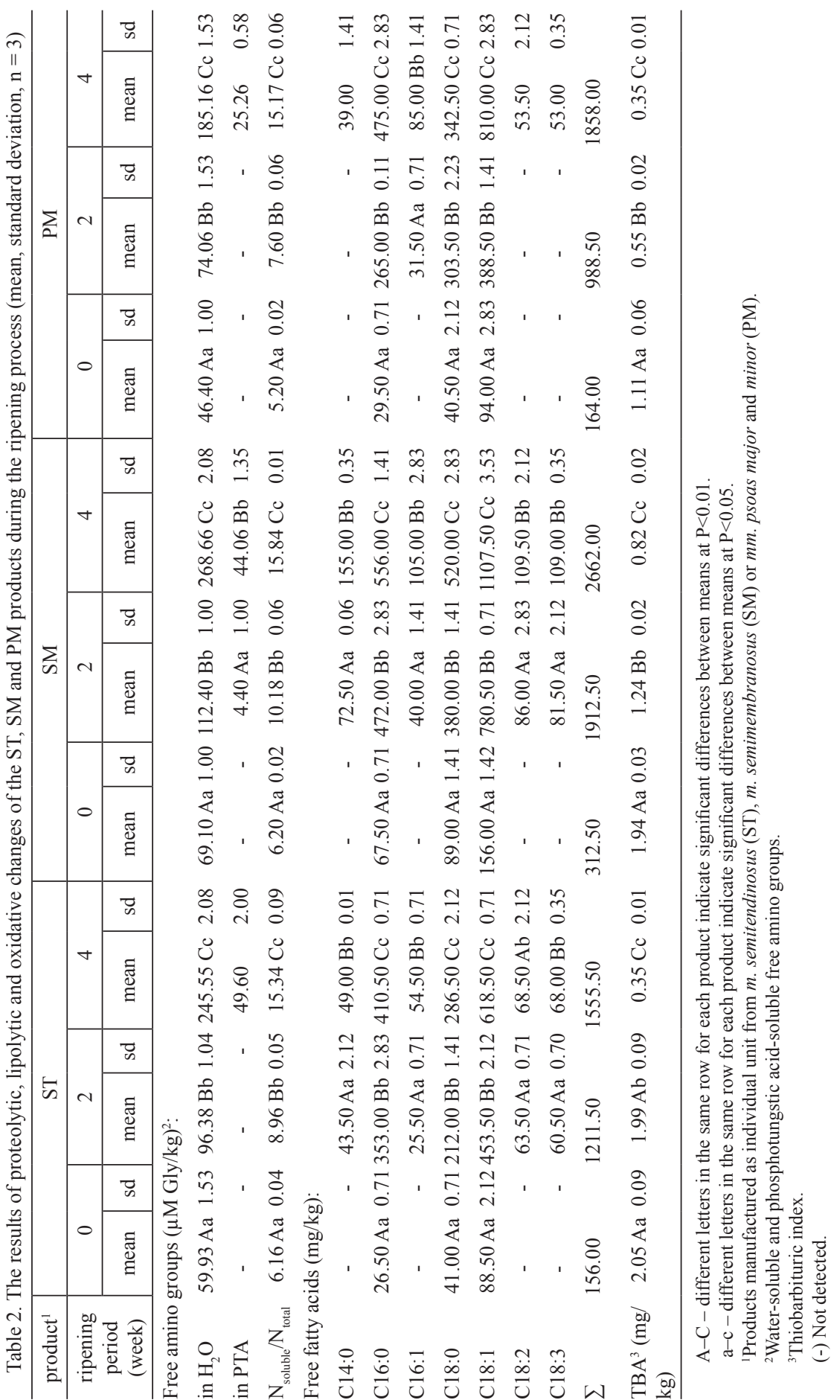




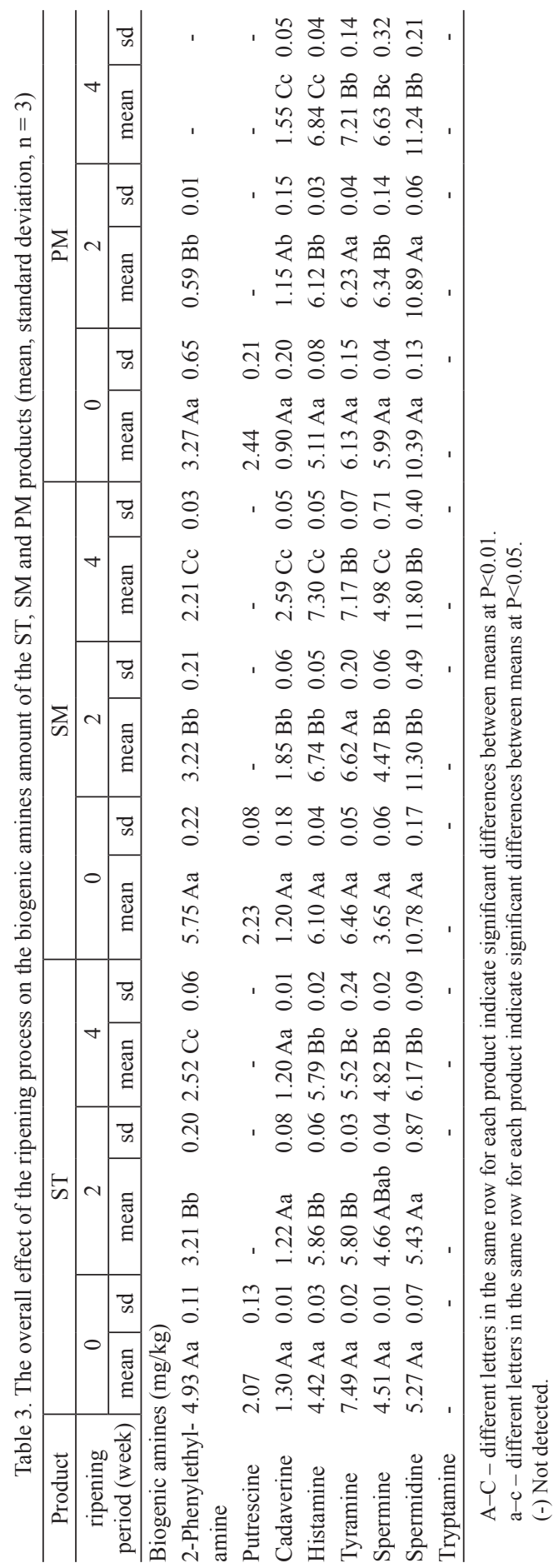




\section{Amount of biogenic amines}

The changes in the amount of biogenic amines are summarized in Table 3. Tryptamine was not found in the ST, SM and PM products. A histamine increase $(\mathrm{P}<0.01)$ in the SM and PM products was noted as compared to their initial values. The content of histamine in the ST product increased $(\mathrm{P}<0.01)$ during the first two weeks and decreased insignificantly during the last two weeks of ripening. Putrescine was not found at the end of the ripening, however, at the beginning it amounted to 2.1-2.4 $\mathrm{mg} / \mathrm{kg}$, depending on the product. Cadaverine and tyramine increased significantly $(\mathrm{P}<0.01)$, from 1.2 and $6.5 \mathrm{mg} / \mathrm{kg}$ to nearly 2.6 and $7.2 \mathrm{mg} / \mathrm{kg}$ of the $\mathrm{SM}$ product and from 0.9 and $6.1 \mathrm{mg} / \mathrm{kg}$ to nearly 1.5 and $7.2 \mathrm{mg} / \mathrm{kg}$ of the PM product, respectively.

\section{Microbial composition}

A gradual increase in the count of aerobic bacteria, yeasts, LAB, coagulasenegative cocci and bacilli $(\mathrm{P}<0.01)$ was observed in the external and internal layer of all products during the ripening process (Figure $1 \mathrm{a}, \mathrm{b}, \mathrm{c}, \mathrm{d}, \mathrm{e}$ ). The count of the aerobic and aerotolerant bacteria was comparable despite the heavy conditions in the external layers, the flow from the slight drying of the products during ripening. Staphylococcus aureus and moulds were not found in any of the products. The following strains were isolated from the ST, SM and PM products: aerotolerant anaerobic bacteria (Lactobacillus xylosus, Lactobacillus acidophilus, Propionibacterium acnes, P. granulosum, Peptonibacterium saccharomyces), anaerobic bacteria (Clostridium bifermentans, C. clostridioforme, C. glycolicum, C. histolyticum, C. ramosum, C. sporogenes, C. subterminale, C. tyrobutyricum, Eggerthella lenta, Finegoldia magna, Gemella morbillorum) and aerobic bacteria (Staphylococcus xylosus, Bacillus cereus, B. subtilis).

\section{Volatile compounds}

The profile of volatile compounds was different for each analysed product and changed during the ripening process (Table 4). Fifteen volatile aroma compounds were detected in the ST and PM products as well as fourteen in the SM product. The majority of them were common for all the analysed products. Following Schmidt and Berger (1998), Meynier et al. (1999), Olivares et al. (2009) and Spazziani et al. (2009), the volatile compounds were grouped depending on their most likely sources: lipid oxidation and microbial metabolism products. The results of lipid oxidation in the ST, SM and PM were: aldehydes (pentanal, 2-pentanal, hexanal, octanal), alcohols (1-penten-3-ol, 3-methyl-3-buten-1-ol, 2-methyl-2-buten-1-ol) and ketones (2-pentanone, 2-butanone, 2-heptanone). Bacteria cells activity could affect: amino acids transformations (3-methyl-1-butanol) and saccharide fermentation (methyl acetate, ethyl acetate as well as butanoic acid) or free fatty acids transformation (2-butanone, 2-pentanone, pentanal, hexanal and 2-heptanone).

\section{Two-way analysis of variance}

The results of a two-way analysis of variance of physico-chemical, biochemical and microbiological attributes in ripened products (Table 5) showed that all the 
analysed factors significantly influenced the level of the evaluated variables in the ST, SM and PM products $(\mathrm{P}<0.01)$ excluding the type of product and its effect on the fat, ash, 2-phenylethylamine and putrescine content, $\mathrm{pH}$ and the coagulase-negative cocci count in both layers of the ST and SM. The interactions between the type of product and the ripening period were highly significant, with the exception of the total bacteria count $(\mathrm{P}<0.05)$ in the external layer, yeasts and the LAB in both layers (not significant).

(a)

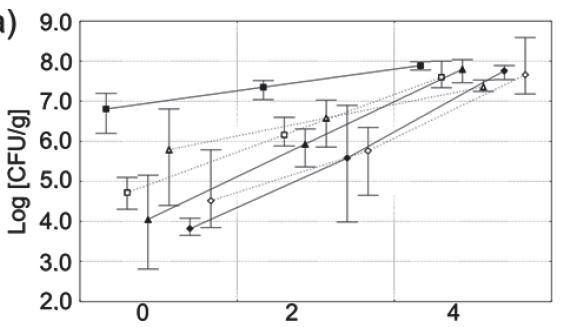

(c)

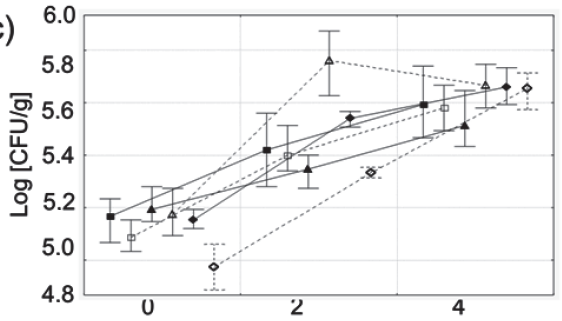

(e)

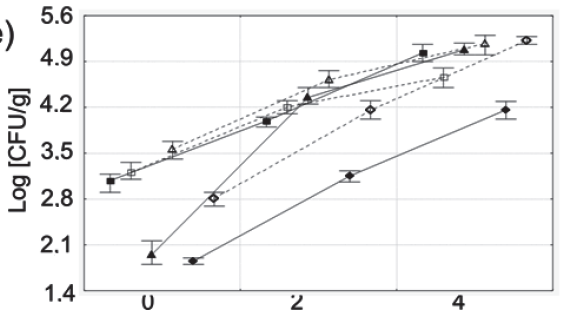

(b)

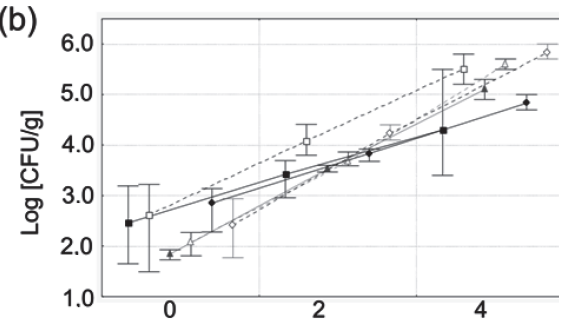

(d)

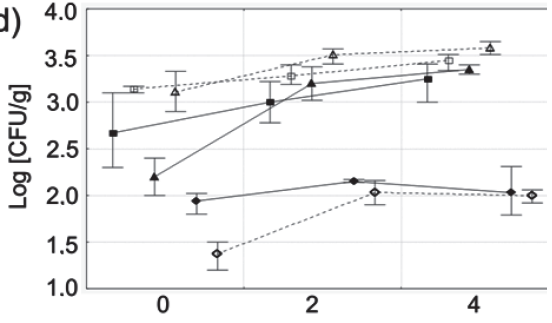

Figure 1. Microflora growth dynamics (mean, standard deviation) in raw fermented beef products (ST, SM and PM) during ripening (0, 2 and 4 weeks): a - total count of aerobic bacteria, b-yeasts, $\mathrm{c}$ - lactic acid bacteria, $\mathrm{d}$ - coagulase-negative cocci, e-Bacillus cereus 
Table 4. The overall effect of the ripening on the volatile compounds of the ST, SM and PM products

\begin{tabular}{|c|c|c|c|c|c|c|c|c|c|}
\hline \multirow{2}{*}{$\begin{array}{c}\text { Product }^{1} \\
\text { ripening period } \\
\text { (week) }\end{array}$} & \multicolumn{3}{|c|}{ ST } & \multicolumn{3}{|c|}{ SM } & \multicolumn{3}{|c|}{ PT } \\
\hline & 0 & 2 & 4 & 0 & 2 & 4 & 0 & 2 & 4 \\
\hline \multicolumn{10}{|c|}{ Volatile compounds (\% of total) } \\
\hline Methyl acetate & 0.84 & 7.79 & 6.55 & 1.10 & 2.76 & 2.49 & - & 2.60 & 2.71 \\
\hline 2-Butanone & 1.29 & 5.58 & 1.16 & - & - & - & - & 5.87 & 2.73 \\
\hline Ethyl acetate & 1.96 & 9.63 & 9.84 & 13.62 & 13.33 & 22.85 & - & 12.55 & 14.03 \\
\hline 2-Butanol & 7.16 & 19.19 & 19.53 & 16.22 & 22.74 & 30.41 & - & 20.93 & 26.95 \\
\hline 2-Pentanone & 5.45 & 10.54 & 12.91 & 5.10 & 18.11 & 12.83 & - & 16.26 & 16.51 \\
\hline Pentanal & 2.41 & 5.86 & 6.35 & - & 4.59 & 2.85 & - & 4.84 & 7.00 \\
\hline 1-penten-3-ol & 1.94 & 4.18 & 4.69 & 2.10 & 4.90 & 3.67 & - & 3.33 & 2.59 \\
\hline 3-Methyl-3-buten-1-ol & 2.15 & 2.83 & 5.88 & 36.09 & 13.29 & 2.64 & - & 2.39 & 5.24 \\
\hline 3-Methyl-1-butanol & 2.44 & 2.44 & 6.72 & 2.10 & 2.31 & 1.48 & - & 2.97 & 5.57 \\
\hline 2-Methyl-2-buten-1-ol & 1.43 & 1.86 & 2.68 & 2.13 & 1.79 & 0.93 & - & 1.14 & 1.64 \\
\hline Hexanal & - & 2.05 & 5.17 & 6.41 & 1.12 & 0.61 & - & 0.80 & 4.74 \\
\hline 2-Pentanal & - & 1.79 & 2.62 & - & 4.88 & 6.50 & - & 0.31 & 0.46 \\
\hline 2-Heptanone & 58.49 & 18.37 & 10.54 & 4.10 & 5.18 & 10.74 & - & 4.52 & 6.02 \\
\hline Butanoic acid & 2.88 & 2.74 & 2.71 & 3.71 & 3.00 & 1.06 & - & 1.30 & 1.61 \\
\hline Octanal & 11.65 & 5.55 & 3.10 & 3.81 & 2.03 & 1.01 & - & 0.63 & 1.46 \\
\hline
\end{tabular}

${ }^{1}$ Products manufactured as individual unit from $m$. semitendinosus (ST), m. semimembranosus (SM) or mm. psoas major and minor (PM).

(-) Not detected.

Table 5. The least squares means from the two-factor analysis of variance of the physico-chemical properties, in relation to the type of product and the ripening period

\begin{tabular}{c|c|c|c|c|c|c|c|c|c}
\hline & \multicolumn{3}{|c|}{ Product $^{1}$} & \multicolumn{3}{c|}{ Ripening period (week) } & \multicolumn{3}{c}{ Source of variance $^{2}$} \\
\cline { 2 - 9 } & ST & SM & PM & 0 & 2 & 4 & P & RP & $\mathrm{P} \times \mathrm{RP}$ \\
\hline
\end{tabular}

Chemical composition (\%):

\begin{tabular}{|c|c|c|c|c|c|c|c|c|c|}
\hline Water & $59.99 \mathrm{Aa}$ & $59.60 \mathrm{Bb}$ & $60.86 \mathrm{Cc}$ & $64.49 \mathrm{Aa}$ & $62.36 \mathrm{Bb}$ & $53.59 \mathrm{Cc}$ & $* *$ & $* *$ & $* *$ \\
\hline Protein & $27.70 \mathrm{Aa}$ & $26.41 \mathrm{Bb}$ & $27.23 \mathrm{Cc}$ & $25.51 \mathrm{Aa}$ & $26.18 \mathrm{Bb}$ & $29.65 \mathrm{Cc}$ & $* *$ & $* *$ & $* *$ \\
\hline Fat & $3.26 \mathrm{Aa}$ & $3.11 \mathrm{Aa}$ & $2.08 \mathrm{Bb}$ & $2.00 \mathrm{Aa}$ & $2.60 \mathrm{Bb}$ & $3.84 \mathrm{Cc}$ & $* *$ & $* *$ & $* *$ \\
\hline $\mathrm{NaCl}$ & $7.82 \mathrm{Aa}$ & $7.67 \mathrm{Bb}$ & $7.24 \mathrm{Cc}$ & $6.15 \mathrm{Aa}$ & 7.57 Bb & $9.01 \mathrm{Cc}$ & $* *$ & $* *$ & $*$ \\
\hline Ash & $9.82 \mathrm{Aa}$ & $9.92 \mathrm{Aa}$ & $8.81 \mathrm{Bb}$ & $8.13 \mathrm{Aa}$ & $9.40 \mathrm{Bb}$ & $11.02 \mathrm{Cc}$ & $* *$ & $* *$ & $* *$ \\
\hline$a_{w}$ & $0.88 \mathrm{Aa}$ & $0.90 \mathrm{Bb}$ & $0.91 \mathrm{Bb}$ & $0.92 \mathrm{Aa}$ & $0.90 \mathrm{Bb}$ & $0.87 \mathrm{Cc}$ & $* *$ & $* *$ & $*$ \\
\hline $\mathrm{pH}$ & $5.64 \mathrm{Aa}$ & $5.65 \mathrm{Aa}$ & $5.52 \mathrm{Bb}$ & $5.90 \mathrm{Aa}$ & $5.74 \mathrm{Bb}$ & $5.16 \mathrm{Cc}$ & $* *$ & $* *$ & $* *$ \\
\hline
\end{tabular}

${ }^{1}$ Products manufactured as individual unit from $m$. semitendinosus (ST), m. semimembranosus (SM) or mm. psoas major and minor (PM).

${ }^{2}$ Product $(\mathrm{P})$, Ripening Period (RP), Product and Ripening Period interaction $(\mathrm{P} \times \mathrm{RP})$.

$\mathrm{A}-\mathrm{C}$ - different letters in the same row for each product indicate significant differences between means at $\mathrm{P}<0.01$.

a-c - different letters in the same row for each product indicate significant differences between means at $\mathrm{P}<0.05$.

** "F" values significant at $\mathrm{P}<0.01$.

* "F" values significant at $\mathrm{P}<0.05$. 


\section{Discussion}

The gradual decrease of $\mathrm{a}_{\mathrm{w}}$ during the last two weeks of ripening could be a consequence of the drying process as well as of the micro-structural and compositional modifications in the products during ripening (Martín-Sánchez et al., 2011) - the water easily evaporated since the isoelectric point was reached. The breakdown of some low molecular components by enzymatic reactions, in particular by lytic activities in tissues, could additionally favour the reduction of $\mathrm{a}_{\mathrm{w}}$ (Patrignani et al., 2007; MartínSánchez et al., 2011). The results of this study confirm the literature reports of Soyer et al. (2005) that the lowest $\mathrm{pH}$ is observed in raw fermented products with a lower fat content. The increase of the free fatty acids together with the lactic acid bacteria development could influence the highest $\mathrm{pH}$ decrease in the SM during the first two weeks of ripening (Spaziani et al., 2009). In ready-to-eat products, acids followed the following order: oleic, palmitic, stearic, palmitooleic, myristic, linoleic and linolenic. A similar tendency was described by Patrignani et al. (2007) and Martín-Sánchez et al. (2011). According to Ansorena et al. (2000) and Lücke (2000), the longer chain free fatty acids $(\mathrm{C} 14-\mathrm{C} 18)$ found in the analysed beef meats, together with products of proteolysis, could have become the precursors of volatile aroma compounds. The low level of TBA index could be the effect of the anti-oxidative activity of smoke components and spices as well as the development of Lactobacillaceae populations (Meynier et al., 1999). The activity of microflora was confirmed by the amount of biogenic amines. The absence or low level of tryptamine, 2-phenylethylamine and putrescine testify to the good quality of the raw meat used (Kalač, 2006; Lorenzo et al., 2007; Stadnik and Dolatowski, 2010). The amount of tyramine can be connected with a level of 2-phenylethylamine. According to Suzzi and Gardini (2003) this phenomenon is an effect of the non-specific activity of the microbial tyrosine decarboxylase. The range of the 2-phenylethylamine amount was lower than tyramine and histamine in the ST, SM and PM products during ripening. A similar tendency, described by Kalač (2006), was explained by an increased temperature and the incorrect conditions in the ripening room. The presence of spermine and spermidine, even in high amounts in meat and meat products, is not alarming (Lorenzo et al., 2007; Stadnik and Dolatowski, 2010). Suzzi and Gardini (2003) concluded that the increase of tyramine and spermine amounts can be the effect of the dynamic growth of LAB and denitrifying microorganisms. Among others, tyramine may occur as a result of Enterococcus activity (Ansorena et al., 2002). The microorganisms originated from ST, SM and PM products constituted the "house microflora" (Leroy et al., 2006). The presence of spore-forming Clostridium, Gemella and Propionibacterium $\mathrm{sp}$. indicated the possibility of fresh meat contamination during the initial postslaughter treatment (skinning, contact with the digestive system mucous membrane) or during salting. Hughes et al. (2002) emphasized the special role of microorganism enzymes in the further degradation of the short-chain peptides and in releasing amino acids. Proteolytic activity of aerobic cocci was already found by Molly et al. (1997) and Olesen et al. (2004) who proved the important role of Staphylococcus carnosus and Staphylococcus xylosus in shortening the time of maturation of fermented sausages and in the degradation of proteins and some amino acid chains (isoleucine, 
leucine and valine) into aldehydes, alcohols and acids, precursors of volatile aroma compounds. The percentage of some volatile compounds (methyl acetate, ethyl acetate and butanoic acid) indicated the highest bacterial activity in the second week of ripening. The percent of 3-methyl-1-butanol gradually increased during ripening. Berdagué et al. (1993), Stahnke (1995), Demeyer et al. (2000), Leroy et al. (2006), Olivares et al. (2009) and Węsierska et al. (2012, $2013 \mathrm{a})$ emphasized the special role of the $\mathrm{pH}$ decrease in the generation of volatile aroma compounds, determined by the type of muscle, technical parameters of the manufacturing process as well as the nature of the biochemical changes, e.g. the increase of myofibril and sarcoplasmic protein solubility, proteolysis, dehydration, lipolysis, fat oxidation, reduction of nitrates (V) to (III), nitrosomyoglobin development and finally fermentation, involving lactic acid bacteria: Lactobacilli rods and lactic acid cocci: Streptococcus sp., Lactococcus sp., Pediococcus sp. and Enterococcus sp.

In conclusion, a decrease of water content (10-11\%) and an increase of protein (3.7-4.5\%), fat (1.5-2.0\%) and ash content (2.5-3.6\%) are associated with the phenomenon of slight drying during the ST, SM and PM ripening process. The readyto-eat ST product contains a similar quantity of water, fat, salt and ash as the SM. In spite of the least loss of water, the largest increment of balanced protein content is observed in the PM product. The accumulation of free fatty acids and the development of the lactobacilli populations cause the $\mathrm{pH}$ value to decrease to 4.9-5.4. The lowest $\mathrm{pH}$ is indicated in the PM with the lowest fat content (2.9\%). Additionally, the acid medium can inhibit the development of coagulase-negative cocci in the ST and SM or even reduce it after the 2 nd week of ripening in the PM by about $0.1-0.2$ $\log \mathrm{cfu} / \mathrm{g}$ in the entire meat volume. For this reason, fractions of peptide degradation are probably $20-50 \%$ lower in the PM in comparison with the ST and SM. Small peptides and volatile compounds were generated at the end of the ripening process in all the products. Reducing the tendency of the TBA index can be considered a consequence of the anti-oxidative activity of the spices, smoke components and the lactobacilli development. The largest decrease of the TBA index is noted in the ST and SM products, by about 1.1 and $1.7 \mathrm{mg} / \mathrm{kg}$, respectively, with the most dynamic growth of lactic acid bacteria during the first 2 weeks of ripening. The increase of tyramine and spermine amounts can be the effect of the dynamic growth of lactobacilli. A considerable part of the "house microflora" includes the species fermenting in the presence of air or in the anaerobic conditions - in the presence of nitrogen. The release of volatile compounds from the matrix, among others 3-methyl-1-butanol, methyl acetate, ethyl acetate, butanoic acid, 2-butanone, 2-pentanone, pentanal, hexanal and 2-heptanone, can be affected by the development of microflora. The drying process, mainly due to the continual rise of fat and its transformation during ripening, is responsible for the presence of 2-butanone, 2-pentanone, pentanal, hexanal and 2-heptanone. 


\section{References}

A n s or ena D., A sti a s a rán I., B e 11 o J. (2000). Changes in volatile compounds during ripening of chorizo de Pamplona elaborated with Lactobacillus plantarum and Staphylococcus carnosus. Food Sci. Technol. Int., 6: 439-447.

B e rda gué J.L., Monteil P., Montel M.C., Talón R. (1993). Effects of starter cultures on the fermentation of flavor compounds in dry sausages. Meat Sci., 5: 275-287.

Body B.A., Arbique J.C., Bourbeau P., Cavagnolo R., Miller J.M., Poole F.M., S h a r p le s N. (2003). Quality Control of Microbiological Transport Systems. Approved Standard, NCCLS, 23 (34).

Cas aburi A., Arist oy M.C., C avella S., Di Monaco R., Ercolini D., Toldrá F., Vil la n i F. (2007). Biochemical and sensory characteristics of traditional fermented sausages of Vallo di Diano (Southern Italy) as affected by the use of starter cultures. Meat Sci., 76: 295-307.

D a $1 \mathrm{~m}$ is Ü., S o yer A. (2008). Effect of processing methods and starter culture (Staphylococcus xylosus and Pediococcus pentosaceus) on proteolytic changes in Turkish sausages (sucuk) during ripening and storage. Meat Sci., 80: 345-354.

Demeyer D., Raemaekers M., Rizzo A., Holck A., De Smedt A., Ten Brink B., Hagen B., Montel C., Zanardi E., Murbrekk E., Leroy F., Vandendriess che F., Lorentsen K., Venema K., Sunesen L., Stahnke L., De Vuyst L., Talon R., Ch i z z o l in i R., E e r o la S. (2000). Control of bioflavour and safety in fermented sausages: first results of a European project. Food Res. Int., 33: 171-180.

Di Cagno R., Chaves-López C., Tofalo R., Gallo G., De Angelis M., P a parel1 a A., H a m m e s W.P., G o b b e t t i M. (2008). Comparison of the compositional, microbiological, biochemical and volatile profile characteristics of three Italian PDO fermented sausages. Meat Sci., 79: 224-235.

Hughes M.C., Kerry J.P., Arendt E.K., Kenneally P.M., McSweeney P.L.H., O'N e ill E.E. (2002). Characterization of proteolysis during the ripening of semi-dry fermented sausages. Meat Sci., 62: 205-216.

K a la č P. (2006). Biologically active polyamines in beef, pork and meat products. Meat Sci., 74: $1-11$.

Kili c B. (2009). Current trends in traditional Turkish meat products and cuisine. LWT - Food Sci. Technol., 42: 1581-1589.

Klont R.E., Brocks L., Eikelenboom G. (1998). Muscle fiber type and meat quality. Meat Sci., 49: 219-229.

K ołc zak T., Palka K., Łą cki J. (2005). Water retention, shear force and texture parameters of cattle psoas and semitendinosus muscles unfrozen and frozen during post-mortem ageing. Pol. J. Food Nutr. Sci., 55: 17-26.

K ołczak T., Krzyszt o forski K., P a l k a K. (2008). Effect of post-mortem ageing, method of heating and reheating on collagen solubility, shear force, and texture parameters of bovine muscles. Pol. J. Food Nutr. Sci., 58: 27-32.

K o ohmarai e M., B abiker A.S., Merkel R.A., Duts o n T.R. (1998). Role of Ca2+- dependent proteases and lysosomal enzymes in postmortem changes in bovine skeletal muscle. J. Anim. Sci., 53: 1253-1257.

Ku chroo C.V., Ramilly I.P., F ox P.F. (1983). Assessment of proteolysis in cheese by reaction with trinitrobenzene sulphonic acid. J. Food Technol., 7: 129-133.

L a r rea V., Hernando I., Quiles A., L 1 u c h M.A., Pérez-Munuera I. (2006). Changes in proteins during Teruel dry-cured ham processing. Meat Sci., 74 (3): 586-593.

Lebert I., Leroy S., Gia m marinaro P., Lebert A., Chacornac J.P., B over-Cid S., Vida l-Car o u M.C., Talon R. (2007). Diversity of microorganisms in the environment and dry fermented sausages of small traditional French processing units. Meat Sci., 76: 112-122.

L e fa u che ur L., Gerrard D. (2000). Muscle fiber plasticity in farm mammals. J. Anim. Sci., 77: $1-19$.

L e r o y F., Verlu y te n J., Vuy st L. (2006). Functional meat starter cultures for improved sausage fermentation. Int. J. Food Microbiol., 106: 270-285.

L orenzo J.M., Matrinez S., Franco I., Carballo J. (2007). Biogenic amine content during 
the manufacture of dry-cured lacón, a Spanish traditional meat product: Effect of some additives. Meat Sci., 77: 287-283.

L ü c k e F.K. (2000). Utilization of microbes to process and preserve meat (review). Meat Sci., 56: $105-115$.

Martín-Sánchez A.M., Chaves-López C., Sendra E., Sayas E., Fenández-López J., Pérez-Álvarez J.A. (2011). Lipolysis, proteolysis and sensory characteristics of a Spanish fermented dry-cured meat product (salchichón) with oregano essential oil used as surface mold inhibitor. Meat Sci. 89: 35-44.

Meynier A., Novelli E., Chizzolini R., Zanardi E., Gandemer G. (1999). Volatile compounds of commercial Milano salami. Meat Sci., 51: 175-183.

Molly K., D e m e y er D., J o han s s on G., R a e ma e kers M., Ghis te lin ck M., Ge en en I. (1997). The importance of meat enzymes in ripening and flavour generation in dry fermented sausages. First results of European project. Food Chem., 59 (4): 539-545.

Moretti V.M., Madoniab G., Diaferiac C., Mentastia T., Pal e aria M.A., P a nseri a S., P i r o n e c G., G an dinia G. (2004). Chemical and microbiological parameters and sensory attributes of a typical Sicilian salami ripened in different conditions. Meat Sci., 66: 845-854.

O le s e n P.T., M e y e r A.S., S t a hn k e L.H. (2004). Generation of flavour compounds in fermented sausages - the influence of curing ingredients, Staphylococcus starter culture and ripening time. Meat Sci., 66: 675-687.

Olivares A., Navarro J.L., Flores M. (2009). Establishment of the contribution of volatile compounds to the aroma of fermented sausages at different stages of processing and storage. Food Chem., 115: 1464-1472.

Patrignani F., Lucci L., Vallicelli M., Guerzoni M.E., Gardini F., Lanciotti R. (2007). Role of surface-inoculated Debaryomyces hansenii and Yarrowia lipolytica strains in dried fermented sausage manufacture. Part 1: Evaluation of their effects on microbial evolution, lipolytic and proteolytic patterns. Meat Sci., 75: 676-686.

P a u ls en P., B a u e r F. (2007). Spermine and spermidine concentrations in pork loin as affected by storage, curing and thermal processing. Eur. Food Res. Technol., 225: 921-924.

R a s on J., La g u e t A., B e rge P., D u four E., L e b e c que A. (2007). Investigation of the physicochemical and sensory homogeneity of traditional French dry sausages. Meat Sci., 75: 359-370.

Ros eiro L.C., Santos C., Sol M., Borges M.J., Anjos M., Goncalves H., Carv a 1 h o A.S. (2008). Proteolysis in Painho de Portalegre dry fermented sausage in relation to ripening time and salt content. Meat Sci., 79: 784-794.

R o s mini M.R., P erlo F., Pérez-A lvarez J.A., P a gán-Mor e no M.J., G a g o - G a g o A., López-S an tovena F., Aranda-Cat a lá V. (1996). TBA test by an extractive method applied to 'paté'. Meat Sci., 42 (1): 103-110.

S a lgado A., García Fontán M.C., Franco I., Ló pe z M., Carballo J. (2005). Biochemical changes during the ripening of Chorizo de cebolla, a Spanish traditional sausage. Effect of the system of manufacture (homemade or industrial). Food Chem., 92: 413-424.

S ch midt S., B erger R.G. (1998). Aroma compounds in fermented sausages of different origins. Lebensm. Wiss. Technol., 31: 559-567.

S o y e r A., Erta s A.H., Üz ü m c ü oglu Ü. (2005). Effect of processing conditions on the quality of naturally fermented Turkish sausages (sucuks). Meat Sci., 69: 135-141.

S pazi an i M., Del Torre M., St e c c hin i M.L. (2009). Changes of physicochemical, microbiological, and textural properties during ripening of Italian low-acid sausages. Proteolysis, sensory and volatile profiles. Meat Sci., 81: 77-85.

S t a d n i k J., D o 1 a t o w s k i Z.J. (2010). Biogenic amines in meat and fermented meat products. Acta Sci. Pol., 9 (3): 251-263.

S tahnke L.H. (1995). Dried sausages fermented with Staphylococcus xylosus at different temperatures and with different ingredient levels - Part II. Volatile compounds. Meat Sci., 41: 193-209.

Suzzi G., Gardini F. (2003). Biogenic amines in dry fermented sausages. Food Microbiol., 88: 41-54.

W ęs ierska E., Szołtysik M., Palka K., Lipczyńska A., Lipczyńska-Szlaur E. (2012). Physico-chemical, biochemical and microbiological changes of "Kumpia wieprzowa" during ripening. Brit. Food J., 115: 1187-1196. 
W ę s i erska E., Korzekwa K., Foks S., Mickowska B. (2013 a). Influence of microflora composition on safety and colour parameters of "kumpia wieprzowa" during ripening. Pol. J. Vet. Sci., 16 (2): 299-305.

W ęs i erska E., S z ołty s i k M., R a k L. (2013 b). Physico-chemical, biochemical and microbiological properties of traditional Polish pork fermented products during ripening. Food Bioprocess Tech., 6, 11: 2986-2995.

W ó j c i a k K.M., D o la t o w k i Z.J. (2012). Oxidative stability of fermented meat products. Acta Sci. Pol., Technol. Aliment., 11 (2): 99-109.

Zha o G.M., Tian W., Li u Y.X., Zhou G.H., X u X.L., Li M.Y. (2008). Proteolysis in biceps femoris during Jinhua ham processing. Meat Sci., 79: 39-45.

Accepted for printing 1 VII 2013 